Vol. 6, n 1 | 2002

Varia

\title{
Blue-Collar Job, Blue-Collar Career: Policemen's Perplexing Struggle for a Voice in Birmingham, Liverpool, and Manchester, 1900-1919
}

Joanne Klein

\section{(2) OpenEdition Journals}

Electronic version

URL: https://journals.openedition.org/chs/229

DOI: $10.4000 /$ chs. 229

ISSN: 1663-4837

\section{Publisher}

Librairie Droz

\section{Printed version}

Date of publication: 1 July 2002

Number of pages: 5-29

ISBN: 2-600-00803-9

ISSN: $1422-0857$

\section{Electronic reference}

Joanne Klein, "Blue-Collar Job, Blue-Collar Career: Policemen's Perplexing Struggle for a Voice in Birmingham, Liverpool, and Manchester, 1900-1919", Crime, Histoire \& Sociétés / Crime, History \& Societies [Online], Vol. 6, n¹ | 2002, Online since 25 February 2009, connection on 23 March 2022 URL: http://journals.openedition.org/chs/229 ; DOI: https://doi.org/10.4000/chs.229

This text was automatically generated on 23 March 2022.

(C) Droz 


\section{Blue-Collar Job, Blue-Collar Career: Policemen's Perplexing Struggle for a Voice in Birmingham, Liverpool, and Manchester, 1900-1919}

Joanne Klein

There is no comparison between what is expected from the policeman of to-day and the policeman of old.... [But] because we have evolved from the 'Bobby of old' to what we are to-day, you are not paying us as much as the lowest paid labourer.

- P.S. George Miles, Liverpool City Police.

[I]t was considered by the authorities that we had means of representation. We put forward that it was not so and that up to the present we have many grievances but have no means of airing

those grievances.

- P.S. Matthew Seaman, Manchester City Police ${ }^{2}$.

1 These two sergeants voiced concerns shared by many in England's police forces at the turn of the twentieth century, that police authorities failed to recognize that police work was evolving into a skilled career. Watch committees continued to identify policemen as unskilled labor since categorizing policing as skilled would require paying the men more. Yet they required policemen to carry out an increasing variety of duties and insisted on police families living in respectable working-class neighborhoods that they could not easily afford. Policemen pointed out the contradiction between their unskilled pay and the expectation that they work and live like skilled workers, but watch committees ignored them. This occurred at the same time that workers across England complained that wages were not keeping pace with inflation, feeding the growth of New Unions which represented both skilled and unskilled labor. Authorities failed to remember that policemen were working class themselves and could not fail to 
notice that their union friends were taken more seriously by employers than policemen were by watch committees. Policemen tried to reason with authorities but without success, leading to growing insistence on an organization to give them a voice and eventually to demands for a police union.

2 The stresses of the First World War combined with continued silence in response to police concerns finally precipitated police strikes in London in 1918 and in Liverpool, Birmingham and London in 1919. The parliamentary committee investigating this embarrassing breakdown of the 'best police in the world' concluded that official ignorance of the state of their own men and watch committees' refusal to listen was the origin of much of the problem. The committee recognized policemen as skilled workers, recommending new scales of pay and conditions of service. While policemen remained skeptical of the Police Federation created to give them a voice, the concession that policemen needed an association of any kind was a gain over pre-strike attitudes. Ironically, due to considerable turnover in personnel due to the war and the strikes, recruits hired under the new conditions became identified with the 'new police' described by P.S. Miles while the men who had struggled to win this recognition rarely escaped the label of 'old.'

Before the twentieth century, policing had been a working-class job classed with unskilled agricultural labor. Three-quarters of recruits left before they reached five years service, and only fifteen percent made it to retirement age. Policemen tried to improve their work conditions but their being unskilled left them in a weak position with local government. Policemen tried petitioning parliament, but the government took its time studying requests. A 1870s and 1880s campaign for pension rights only succeeded after the 1889 Great London Dock Strike convinced parliament that they needed reliable policemen during tumultuous union activity. By the turn of the century, policing was changing. Between 1900 and 1919, only forty percent of Manchester City Police recruits left with less than five years service, and forty percent made it to retirement age ${ }^{3}$. A similar pattern appeared in Liverpool and Birmingham. Changes in conditions of service contributed to this shift, particularly the 1890 Police Act which guaranteed pensions after twenty-five years of service or fifteen years for medical disability ${ }^{4}$. Others factors were new duties such as traffic duty, first aid, and child welfare, and new skills as wireless operators, auto mechanics, and photographers. Recruits needed a better education to handle the new responsibilities. The combination of pensions and more complex duties attracted men looking for long-term rather than short-term employment.

With pension rights and increasingly diverse duties, policemen began thinking in terms of a police career. But they learned that even national legislation could not change local governments' views on policing. Watch committees, the legal authorities that dealt with police conditions of service in borough forces such as Birmingham, Liverpool and Manchester, held onto traditional definitions of policing in order to economize. Locally, pensions were tied to age in addition to time served to delay paying them for as long as possible. Watch committees were reluctant to recognize that pay scales were failing to keep pace with inflation, let alone to consider upgrading scales to skilled levels. Higher pay meant higher pensions for policemen, another reason to keep pay scales low. Another problem with national legislation was that it could not solve local problems with discipline, corruption, and favoritism. 
5 Policemen noticed that they were working harder while their pay scales were eroding. Yet they lacked an effective way to influence watch committees and chief constables. The obvious option of a union was not realistic even when they saw unions working for their friends. Most policemen agreed that a police union conflicted with their oath of office to serve the king, preserve the peace, and discharge their duties according to $l_{a w}^{5}$. A police union that could challenge authorities or declare a strike was generally seen as inconsistent with keeping the peace. This was especially true for men thinking of a police career. The public nature of a challenge to authority could tempt civilians to call into question the good standing of the police system. In addition, many policemen hesitated to consider direct action for fear of losing their pensions. Instead, they tried to improve their situation using tactics within the accepted boundaries of police behavior. This generally meant petitioning watch committees. Sometimes petitions met with success but mostly they did not.

Policemen tended to be more willing to voice their concerns in police forces with better relationships between chief constables and the ranks. Policemen in the City of Manchester frequently organized delegations and petitions since their chief was considered to be willing to listen. Chief Constable Robert Peacock (1898-1926) began his career as a beat constable in Manchester, so he understood the struggles of local beat life. The city force was by no means free from corruption, but its reputation was better than many. In the City of Liverpool, Head Constables ${ }^{6}$ John William Nott Bower (1881-1902) and Leonard Dunning (1902-1912) began their careers in the Royal Irish Constabulary, more of a military organization than a police force. This led to too much distance and a lack of understanding between them and their men. The Liverpool force tended to be described as 'seething' and its morale was poor. While factions and corruption were common elsewhere, Liverpool was a national by-word among policemen for nepotism, patronage, and religious turmoil ${ }^{7}$. Chief Constable Charles Rafter of the City of Birmingham (1899-1935), also Royal Irish Constabulary, was autocratic even for that body, continually stressing the importance of unquestioning 'loyalty to the force'. The men had to petition Rafter for permission to discuss force issues amongst themselves. This discouraged them from petitioning for better pay and conditions, and left their watch committee more misinformed than most about the morale of their policemen.

7 At the same time that policemen faced barriers communicating with authorities over them, they acquired a way to communicate with each other across force lines. In 1893, John Kempster founded the Police Review and Parade Gossip, a national publication to provide a forum for policemen to air their grievances and to compare local conditions ${ }^{8}$. Letters to the Review allowed policemen to share their hopes and fears with each other. Policemen wanted regular days off and better pay; they wanted to clean up corruption and favoritism that endangered promotions and pensions; and they wanted their work recognized as skilled. Since policemen did not have a union or association, the Review provided an important resource for coordinating pressure put on both local and national government. It supplied information on different forces that policemen could use to assess local conditions within a national context and to strengthen requests for improvements at home. The Review helped foster a sense of national camaraderie for policemen, representing the potentially dangerous reality of policemen finding common cause with each other at the same time that they felt estranged from those above them. 
8 In 1900, with help from the Review, policemen across England began pressuring watch committees for improved pay since most pay scales had not been adjusted since the 1890 Police Act. Policemen remembered that it had taken a great strike to gain pensions, and hoped that growing strike activity might convince governments to take their petitions seriously. To launch this effort, the Review published a list of a hundred and twenty-two English borough rates of pay for constables, including the strength of each force and age or time required for pensions. Manchester and Birmingham constables began at twenty-four shillings a week, and Liverpool at twenty-five shillings, with seven pence going to the pension fund. This was typical of borough forces regardless of size ${ }^{9}$. Watch committees delayed pay increases as long as possible, arguing that policemen were not considering their free medical care, uniforms, boots, and rent allowances in addition to pay. Policemen countered that these items did not figure into their pensions. But watch committees, answerable to local rate payers, proved difficult to convince.

9 In March 1900, a delegation of Manchester inspectors, sergeants and constables petitioned their watch committee, an unusual combination of ranks that reflected the more open climate in their force and gave their petition more weight. They pointed out that their scale of pay had been set in 1890 and did not keep pace with inflation. In consequence, they were paid less than «all classes of workmen» yet «if we are to maintain an independent and respectable station in life, it is absolutely necessary that our wages should be increased to enable us to do so». Policemen were expected to practice «conduct becoming a police officer» both on and off duty. By 1900, as their responsibilities grew, this meant respectable artisans' behavior. Policemen accepted this since they hoped to see policing recognized as a respectable career. The watch committee postponed consideration of the petition for economic reasons ${ }^{10}$. However, at the same time, Chief Constable Peacock's salary was raised from £800 to $£ 1000$ per annum to reward him for economies that saved the city $£ 4000$ a year ${ }^{11}$. A Manchester inspector wrote to the Review, «it seems hard that their request for increased pay should have to be put back because the authorities have been too lavish in their expenditures $»^{12}$. This echoed other letters criticizing watch committees for underpaying their police forces to «save rate payers» or to compensate for overspending elsewhere. In February 1901, the watch committee finally granted a raise of a shilling a week ${ }^{13}$. While better than other cities were willing to offer, it kept Manchester's pay within the 1900 national average.

10 Liverpool sergeants and constables submitted a petition in July 1900 similar to Manchester's but without the help of inspectors ${ }^{14}$. They included more detailed financial evidence to back up their requests, perhaps learning from Manchester's initial failure. They began with basic figures, including rent increases from six pence to a shilling over the last five years. They pointed out that they did not have the option of seeking cheaper housing in less respectable neighborhoods since housing had to be approved. They gave details on artisans' wages ten to fifteen shillings a week higher than police wages, and yet policemen were «expected to keep up a position equal to them and to clothe our children respectably». Unlike Manchester, they provided detailed comparisons to forces with better pay and conditions, hoping this could help their case. In spite of this effort, the watch committee rejected most of the petition. In November, they granted first-year constables an additional seven pence a week but nothing more ${ }^{15}$. 
11 Birmingham men seemed too intimidated by Chief Constable Rafter to petition though much unofficial grumbling took place. Letters in the Review belittled the Birmingham city motto of 'Forward' since their policemen were among the last to ask for, let alone receive, a pay raise ${ }^{16}$. Finally, in November 1901, 'A' division solicited permission from Rafter to meet and put forward a delegation to the watch committee regarding pay, duty, and leave ${ }^{17}$. That same day, Rafter wrote a letter to one of his superintendents expressing his deep distaste for 'subversive activity'. He considered

furtively signing a round-robbin, circulating anonymous circulars among members of the Force, unauthorised or secret meetings, anonymous letters to the press putting forward alleged grievances derogatory to the character and discipline of the Birmingham City Police Force... highly insubordinate and reflects discredit... upon those... taking part in such proceedings ${ }^{18}$.

He was particularly annoyed by 'paragraphs' showing up in local newspapers. While he gave permission for the 'A' divisions to meet, their petition was shelved by the watch committee during the Lloyd George riots in December and was then 'lost' ${ }^{19}$. This simply encouraged his men to keep to 'subversive' tactics. In 1903, constables and sergeants finally petitioned the watch committee again. They decided to request not only better pay but also more leave and a major change in their shift system. Possibly, they hoped that by asking for three changes, they might at least gain something. Their pay demands succeeded when the committee investigated the petition's claims and found that most principle forces in England had revised their scales of pay in 1900 and 1901. However, the new scale was a mixed blessing, giving one and two shilling raises to some men but nothing to others. The committee granted two additional days of leave per year as well. Given the lateness of the city's pay increase compared to elsewhere, the leave days were needed to attract recruits who were avoiding Birmingham. The hope for substantial change in the shift system failed ${ }^{20}$. Birmingham had such a bad reputation that the Review called its watch committee «the most indifferent and the meanest towards its Police of all the great corporations in the country» ${ }^{21}$.

The unofficial organizing that Rafter complained about in Birmingham was also appearing in Liverpool. In 1907, constables elected delegates to write a strong petition for better pay and additional annual leave. The delegates created an elaborate document. They first presented a detailed weekly budget of a married man with two children, receiving $£ 1 / 13 / 3 \mathrm{~d}$. a week. Expenses for rent, coal, groceries, and friendly societies came to $£ 1 / 10 / 9 \mathrm{~d}$. They pointed out that this did not include anything for clothing, newspapers, the doctor, holidays, tram fares, and church. They detailed how prices had increased while their pay remained the same, making it impossible «to keep up a respectable appearance required of him and his family». They emphasized that rent allowances were only given for «approved» neighborhoods where they could not afford to live. They compared their scale of pay to police forces in Leeds and Blackburn. They insisted that «we are entitled to have justice meted out to us». The petition was signed «on behalf of the elected delegates from each Division representing 1605 Constables». In spite of their appeals to respectability and justice, the watch committee was «unable to accede to the constables' request $»^{22}$.

Petitioning resulted in some limited success but mostly in failure, leading to growing frustration as pay scales continued to erode. Not surprisingly, policemen connected their inability to get results to their inability to organize. The idea of a police union was not new, policemen having flirted with the idea in the previous century. But deteriorating pay, ineffective petitions, and the national forum provided by the Review 
led to increasing debate over the need for strong representation. Growing union activity by other workers led policemen to wonder how they could improve their own lot. They tried to find some solution short of a 'real' union but were baffled by how to give such a group the influence they needed. 'Brum' believed that policemen should support the Police and Citizens Association (PACA), a lobby and 'self-help' group which Kempster promoted in the pages of the Review ${ }^{23}$. But while PACA had appeal, it could not address local problems with discipline and promotion. 'One and All' suggested that police pensioners be delegated to represent different forces at conferences to discuss matters and to lobby national and local government ${ }^{24}$. Men debated the benefits of having a full trade union with a right to strike versus a federation with the right to confer. Disagreements could be sharp, showing internal divisions over what direction to take. A Birmingham policeman wondered why chief constables could have an association but the rank and file could not. He went so far as to consider «the feeling of this Force... akin to that of Russia against its autocratic government» ${ }^{25}$. While most believed that they had a right to an organization, many felt great ambivalence towards the right to strike. They knew that a police 'down tools' would endanger neighborhoods and businesses; a Liverpool constable believed it was wrong for policemen to «throw the general public to the wolves ${ }^{26}$. Some but not many supported the idea of associating with the Trade Union Conference (TUC), creating the problem of sympathy strikes for and by policemen. Most recognized the conflict of interest between policing strikes and striking themselves. But regardless of reservations, policemen wondered what options they had if authorities refused to listen.

Joseph Kempster, alarmed by the growing number of letters to his Review supporting a union, began a national campaign in January 1906 to lobby local and national government to grant policemen a weekly rest day. He hoped its success would demonstrate to policemen that options to a union still existed. But similar to the 1900-1901 pay scale drive, watch committees were slow to respond. In 1907, Birmingham approved an increase to two days per month for sergeants and constables which required the hiring of twenty-six more men ${ }^{27}$. In 1908, Manchester policemen were granted one day off a fortnight. But watch committees used granting days off as a reason not to increase pay. In 1909, Manchester sergeants petitioned the watch committee to place their pay on a similar scale to sergeants in other forces, but without success since they had received days off the year before ${ }^{28}$. Getting watch committees to improve policemen's conditions of service remained an agonizing process. 'Cui Bono' compared policemen to Saxon slaves, where masters could grant requests and be seen as benevolent but slaves could not make those same requests without being labeled disloyal ${ }^{29}$.

It took four years for the weekly rest day to be implemented nationally. In 1909, in the midst of considering legislation on pensions, national insurance and minimum wages, parliament granted the Metropolitan and City of London Police Forces a weekly rest day. A constable outside of London remarked, «Why the Metropolitan should be singled out for this boon we fail to see, except that they happen to be constantly under the eye of Parliament $\aleph^{30}$. Some forces followed London's lead but not all. The Birmingham watch committee postponed consideration of a weekly rest day «pending a definite expression of opinion from the rate payers as to whether that expense should be incurred $\aleph^{31}$. A 'Manchurian' described how a deputation had been told by their watch committee that «they must be able to give a reason for spending an extra $£ 10,000$ a year $»^{32}$. A Liverpool constable warned of dangerously low morale due to this foot- 
dragging while policemen elsewhere got their day ${ }^{33}$. A Birmingham constable pointed out the hypocrisy of his city, "Surely our city Fathers are not withholding this righteous boon from a deserving body of public servants on the plea of economy, whilst their employees in other departments are enjoying this precious privilege $»^{34}$. Policemen felt unappreciated and neglected. Finally, growing strike activity nationally made the idea of police unrest unattractive to the national government. Parliament enacted the Police Weekly Rest Day bill in 1910, recognizing the justice of complaints that London police had benefited from being under the government's nose.

But watch committees refused to implement the rest day completely, similar to their modification of the 1890 pensions law. Letters to the Review complained that the rest day was not being implemented due to various 'emergencies,' usually tied to strikes. This aggravated policemen who thought that their efforts had finally prevailed. Watch committees failed to consider how growing union activity might influence policemen. Watch committees' tendency to use lack of money to evade improving police conditions of service, even when mandated by national legislation, reinforced the belief that policemen needed some means of genuine leverage. Kempster's attempt to demonstrate that lobbying governments could be a successful alternative to organizing had backfired.

After years of being 'economized' and of futile petitioning, police unionism was 'in the air.' Miners, transport and railway workers were unionized and staging a strike epidemic. This added to police work loads and stressful overtime as well as police frustrations with their own lack of options. They continued petitioning but failures reinforced the conviction that policemen needed a union. Birmingham policemen stopped petitioning altogether and Rafter heard rumors of a local police union in 1911 during the national railway strike ${ }^{35}$. In 1912, Liverpool constables asked for permission to form a union; not surprisingly the watch committee refused ${ }^{36}$. That same year, Francis Caldwell took over as head constable, a product of the hated 'office clerk' track rather than the street beats. This seemed to confirm all that was wrong with Liverpool, making petitioning seem pointless ${ }^{37}$. In 1911 and 1912, Manchester constables petitioned for higher pay but the watch committee rejected both requests ${ }^{38}$. One Manchester constable challenged his colleagues, «Are you going to let the authorities 'economise' for ever, at your expense? ${ }^{39}$. Another Manchester constable wondered why, «when the whole industrial community is at war with the powers that be, the Police forces of this country are apparently the weakest set of men in the whole community». He suggested that policemen «take advantage of the great opportunity which now presents itself», that they use the industrial «war» to their advantage ${ }^{40}$. The formation of a Paris police union in 1912 encouraged policemen and worried authorities ${ }^{41}$. In September 1913, an advertisement appeared in the Review informing London police that they could secretly join a union there ${ }^{42}$. In support of this idea, a Mancunian observed that tram drivers made much better pay than policemen because of their union, but that policemen were «not organised, and have nothing behind to back us up $»^{43}$. Belligerent letters to the Review reveal the impatience resulting from seeing friends benefit from unions while policemen had nothing ${ }^{44}$.

In October 1913, in a sign that Birmingham policemen had organized regardless of orders against it, three to four hundred men protested against inadequate compensation for extra duty during a railway strike by refusing to sign their pay sheets. This approached nearly half the force. Their objections came as a complete 
surprise to Rafter, a sign of the lack of communication between higher and lower ranks. Efforts to change the pay award were ignored as the actions of a «few grumblers» ${ }^{45}$. Soon after the failed protest, rumors of «an association within the Police Force» reached Rafter, who immediately reminded his men of rules against private meetings of policemen ${ }^{46}$. But at least some Birmingham men were so frustrated with Rafter that they created an association anyway. As reported in the Birmingham Evening Dispatch, they aimed to insure fair promotions, give legal representation in discipline cases, fully implement the weekly rest day, and achieve better pay and allowances. The association secretary believed that joining was not a breach of force rules but Rafter begged to differ. In a police order, he stated that such meetings were contrary to rules of service unless of a «legitimate purpose» cleared with the chief constable ${ }^{47}$.

The Birmingham association was just one of a number of small local unions formed by a core of men around the country, frustrated with the refusal of authorities to listen. Worried about the militant tone of letters to the Review, Kempster tried to suggest a federation or board as an alternative to a union ${ }^{48}$. But his readers showed little interest in this idea $^{49}$. This trend was serious enough that in November 1913, the Under Secretary of State sent a circular letter to all chief constables, stating the government's position that «it was impossible to allow a Union or Association to be established in an organized and disciplined Force where ready obedience to the orders of a superior officer was a condition of service accepted by all who joined the Force, and essential to its existence $\aleph^{50}$. Unfortunately, in light of later developments, police authorities and governments had no constructive response to the growing unrest.

21 The outbreak of war on 4 August 1914 muted calls for a police union but the strains of war soon caused frustrations to break out more forcefully. Just before the war, Birmingham had granted new scales of pay starting at twenty-nine shillings a week ${ }^{51}$ but almost immediately had to grant their men non-pensionable bonuses in reaction to wartime inflation. Other forces followed suit. Authorities made it clear that they considered bonuses to be temporary since prices were expected to return to pre-war levels once the war ended ${ }^{52}$. Adding to the strain, each force set its own bonus rates, varying from two to twelve shillings, creating resentment against watch committees which set low amounts ${ }^{53}$. Manchester men did not receive war bonuses at all, perhaps since they had received a pay raise beginning at twenty-eight shillings a week in January ${ }^{54}$. In October 1915 letters to the Review, Mancunians complained that they were being disciplined for not paying their just debts yet they received no bonus ${ }^{55}$. In March 1916 three Manchester divisions finally petitioned the watch committee, declaring that they had «loyally refrained from petitioning for more pay until we cannot now obtain bare necessities and view with alarm the continued rise in the cost of all commodities $\aleph^{56}$. An editorial in the Review expressed concern that Manchester policemen were losing confidence in authorities to treat them honorably, tempting them to join a police union active in London ${ }^{57}$. In April, they finally received extra day duty pay of six shillings a week ${ }^{58}$. Only in January 1917 did Manchester grant policemen a war bonus of seven shillings a week ${ }^{59}$.

Even with bonuses, police pay did not keep pace with wartime inflation, which raised the cost of living by anywhere from eighty to 130 percent $^{60}$. Men and their families were forced to violate conditions of service against outside employment to pay bills ${ }^{61}$. Forces were losing men to high-paying war occupations, putting more pressure on the men who remained. Some wondered if this attrition was a deliberate plot by watch 
committees to get out of pension obligations. In June 1917, Birmingham policemen sent a memorial to their watch committee begging for their bonus to be raised. While receiving a raise to nine and a half shillings, they knew that other forces received twelve shillings or more ${ }^{62}$. Also in June, wives of Liverpool constables in his majesty's forces complained to the watch committee that their allowances were inadequate; in October Birmingham wives followed their example. The cities had to raise wives' allowances to twenty shillings a week to avoid embarrassing publicity ${ }^{63}$. Police bonuses were raised with increasing frequency in an attempt to match inflation, but only after pressure from policemen ${ }^{64}$. Letters to the Review from men and their wives became more bitter and angry as the war continued, often aimed at the authorities who were supposed to protect their interests. A Manchester constable wrote in August 1917,

«a point I should like to draw the Authorities' attention to is that not being allowed to organize, they should not allow us to be scoffed at by our neighbors, who can force their demands through trade unions. We have to purchase in the same market as these men who receive 100 percent more pay. We appeal to the Authorities to remember that when dealing generously with trade union men not to forget their public servants, the Police, who are absolutely in their hands» ${ }^{65}$.

Pre-war frustrations over slow responses from watch committees became intensely focused under the pressures of war. Resentment escalated when policemen were told that demands for more pay were disloyal and unpatriotic.

On top of anxieties over pay, the war undermined the one area of police success, the weekly rest day. Like pay, leave days were handled chaotically. On 5 August 1914 Manchester policemen were told that «leave to all members of the Force will be stopped at once». By the end of November this was revised, allowing one day off in fourteen. In January 1915, one day in seven was restored only to be changed back to one day in fourteen in June as the number of police sent to the front lines increased ${ }^{66}$. In Birmingham, leave was stopped from August to October 1914, changed to two days a month, back to a weekly rest day from November 1914 to November 1915, then changed back to two days a month for the remainder of the war ${ }^{67}$. In Manchester, the men were paid for the extra days they worked beginning in 1916; in Liverpool they were paid beginning in 1917; in Birmingham, pay arrangements for lost rest days were not made until January $1919^{68}$. A Liverpool policeman complained that while suspending the rest day for a reasonable period was acceptable, doing so indefinitely was not. When «seething discontent» in that city forced the watch committee to allow one day in ten in December 1914, the committee accused the men of being unpatriotic. The police responded by organizing a boycott of their weekly War Fund contributions ${ }^{69}$. The watch committee then changed rest days back to one day a fortnight. The constant fluctuation of policies left policemen wondering about the competence of their leadership.

By the end of 1917, policemen had had three years of non-pensionable bonuses on top of inadequate pensionable pay scales. Men complained that denying them pensionable wages for so long seemed like yet another way for local authorities to economize at their expense. Watch committees finally began adopting new scales of pay as well as increasing bonuses, war pressures giving policemen more leverage. In October, Birmingham raised pay to thirty-one shillings a week ${ }^{70}$, in November, Liverpool adopted a scale starting at thirty-five shillings. But Manchester was late again. In January 1918, a Manchester constable advised local authorities that if they did not "wake up» and pay the men a just wage that they «will be wanting Policemen after the war ${ }^{71}$. Finally, in March 1918, Manchester adopted a scale starting at thirty-five 
shillings, and increased their bonus to sixteen shillings ${ }^{72}$. Even with these improvements, police wages were low compared to other workers, leaving them with unskilled status at the same time that wartime duties threatened to overwhelm them.

With authorities insisting that the new pay scales were basically adequate, policemen began to listen to the National Union of Police and Prison Officers (NUPPO). Originating in the London Metropolitan area, NUPPO branches began to appear in the provinces, especially after the union adopted a 'no strike' policy in 1917. A month after granting the belated pay raise, the Manchester watch committee expressed surprise that a NUPPO branch existed in their city when a delegation of five union members appeared before them. The committee reminded the men that «every facility is given to members of the Force who desire to bring any grievances they may have before the Chief Constable or the Watch Committee $»^{73}$. They knew of no cause for dissatisfaction in the Manchester police force, in spite of their delays in granting pay and bonus increases. In August 1918, Peacock complained to the Home Office that P.C. Thiel of London was agitating for the NUPPO in Manchester. In response, Thiel was dismissed on 25 August 1918. Sensing trouble, Peacock convinced the watch committee to reinstate the weekly rest day on 22 August, to begin 1 September, and to raise the war bonus to twenty shillings. The existence of a local NUPPO branch had convinced the watch committee to take police complaints seriously and they listened to Peacock. He announced this news to the men on 29 August $^{74}$, the same day that the Metropolitan and City of London police forces struck for better pay, recognition of the union, and reinstatement of Thiel ${ }^{75}$. Catching many policemen by surprise, NUPPO leadership had abandoned the 'no strike' policy.

The 1918 London police strike caused major problems for the government since the NUPPO's demands for better wages were publicly perceived as just ${ }^{76}$. Even The Times, which called the strike a mutiny, believed that the policemen had a legitimate case ${ }^{77}$. Memories of the part played by disaffected policemen in the Russian revolution were at the back of the government's mind. Left with few options, Prime Minister Lloyd George issued the new 'Met scale' starting at forty-three shillings with a twelve shilling war bonus. He promised to investigate grievances by setting up the Committee on the Police Service of England, Wales, and Scotland, more commonly known as the Desborough Committee. None of the strikers was dismissed; Thiel was reinstated; and Lloyd George created the impression that the NUPPO would be recognized after the war by declaring that the union could not be recognized during wartime ${ }^{78}$.

In spite of a general feeling among policemen that they should not be able to 'down tools', the question remained why a strike had been necessary before authorities listened to police grievances. London police commissioners had insisted that no serious unrest existed in their forces only days before the strike began, similar to Manchester's surprise that their men had unionized earlier in the year. Both incidents show how serious the lack of communication between authorities and policemen had become. In hindsight, Sir Arthur Dixon from the Home Office realized that «the absence of any regular machinery for the submitting of local or collective representations left grievances in too many instances without any satisfactory outlet, and this led to increasing agitation for the 'right to confer' and to the appearance of [the NUPPO]» ${ }^{79}$. The Review considered this lack of machinery for policemen to discuss and present grievances regarding conditions of service to be the sole cause of the strike ${ }^{80}$. For 
decades, policemen had tried to communicate with those in authority and the authorities had no incentive to listen to them.

After the strike, watch committees everywhere quickly adopted the 'Met scale' to prevent union trouble from spreading to their own forces. The rapid adoption of the scale gave the impression of authorities scrambling to react to events. But better pay was not enough to silence police grievances. Policemen now had concrete proof that a union could bring fantastic results. Other forces suddenly had active NUPPO branches, much to the horror of chief constables who preferred to assume that 'their men' would not follow London's example. The NUPPO claimed 50,000 members in November 1918. Even more disturbing for authorities, NUPPO's concerns often focused on systemic problems of corruption, favoritism, promotion, assignments and discipline rather than simple pay issues ${ }^{81}$.

In Manchester, to counteract NUPPO influence, chief constable Peacock quickly arranged to hear from his men directly. On 5 September 1918 he gave permission to a committee of sergeants to institute «a scheme for providing representative committees to deal with matters relating to the Police Service» ${ }^{82}$. In spite of this, the Manchester branch of the NUPPO remained vocal, their main concern being pay. In early October, they sent a delegation to Peacock requesting that the union be recognized, that pay be raised one hundred percent, and that a non-contributory widow's pension be created. He replied that their current scale and bonus matched the Met scale and expressed skepticism about NUPPO claims to represent the force. The Manchester union went so far as to threaten to strike at this reply but decided to give the watch committee time to adopt a new pay scale ${ }^{83}$. Peacock issued a general order reminding policemen of regulations against a union but also announced that he was «desirous of speaking to the members of the Manchester City Police on the question of Pay and Conditions of Service». He arranged to meet with all ranks at Central Hall on 9 October ${ }^{84}$. He allowed the men to decide whether they should keep their current pay, which matched the Met scale but included a twenty-shilling non-pensionable bonus, or if they preferred to adopt the Met scale. Favoring pensionable pay, the men requested and received the Met scale $^{85}$. Peacock's willingness to meet with delegations helped prevent disputes from getting out of control. But that it had taken the London strike to gain this consideration, similar to previous gains only coming in response to crises, was a lesson not lost on the men.

Liverpool Head Constable Caldwell's tactics were similar to those of Peacock, immediately allowing his divisions to meet to discuss pay and conditions. In September, the men held mass meetings that involved all ranks, even though Caldwell had advised them to limit meetings to delegates from each division. On 25 September, based on their decision, the city adopted the Met scale ${ }^{86}$. On 7 October, Caldwell announced that his men could vote whether to adopt a flat sixteen shilling war bonus or to keep the twelve shilling Met bonus that added two and a half shillings per child, stating that he was «desirous of ascertaining the opinion of the majority of the members of the force $\|^{87}$. However, unlike Manchester where the main problem was pay, Liverpool men were concerned with entrenched favoritism and corruption. That same month, rumors estimated that ninety percent of the Liverpool force had joined the NUPPO because, as P.C. Smithwick remarked, «more promotions were made by the back door than the front $»^{88}$. Caldwell himself symbolized promotion based on connections rather than street experience. While visiting Liverpool in October, Birmingham Chief Constable 
Rafter learned that London P.C. Thiel was there to help organize the local branch of the NUPPO ${ }^{89}$.

31 In Birmingham, Chief Constable Rafter was less diplomatic than Peacock or Caldwell. The watch committee adopted the Met scale on 2 September ${ }^{90}$ but unlike elsewhere, Rafter did not call force meetings to discuss the new pay scales. His men understood the futility of sending NUPPO delegations to talk to him. On 7 October, when Peacock and Caldwell were allowing force meetings, Rafter issued a statement allowing for a permanent elective representative committee to study grievances and handle requests for meetings. This was as far as he was prepared to go. At the same time, he reminded the men that both he and the watch committee looked after their interests and that the London strike had been a shameful act ${ }^{91}$. However, his sharp condemnation of the London strike and the NUPPO did not deter his policemen from organizing a union branch. Rafter was infuriated to read in a local newspaper that the Trades and Labour Council had received an application for affiliation from the newly formed NUPPO branch in Birmingham ${ }^{92}$.

At the same time that chief constables were responding to the strike locally, the national government recommended that representative boards be created as an alternative to the NUPPO. But the boards were not a general success. Either watch committees refused to take them seriously, or policemen saw them as a tool of the authorities to undermine the union. Birmingham policemen disliked the boards since they could only present their case and retire; the watch committee made decisions in camera $^{93}$. In spite of this lack of consultation, the board did eventually get leave restored and payment for leave lost due to the war ${ }^{94}$. Knowing that Rafter would never tolerate the NUPPO, supporters of the board decided to be realistic and take what representation they could get. But others hoped for more, creating dissension within the ranks. In Manchester, when their representatives tried to present various grievances, watch committee members «were drawing different figures and different animals, etc., on the papers, taking no notice; others were going in and out of the room $»^{95}$. In February 1919, Manchester policemen declared the representative boards disbanded and that all further business should be given to their NUPPO branch. They told Peacock that he had failed to keep the promises he made at the October meeting ${ }^{96}$. Caldwell allowed Liverpool policemen to vote on whether or not to set up representative boards. The vote was 449 in favor of the boards and 738 against, with nearly a thousand not voting at all ${ }^{97}$. In light of the vote, Caldwell decided not to create boards but failed to respond to the danger signals the vote results indicated. Less than a quarter of the men considered it worthwhile to try the boards. Many believe that the boards would come under the control of some faction; many thought official representation was pointless given the entrenched networks in the force; many preferred the union. Overall, the boards were too obviously meant as a government alternative to the union.

The successes of 1918 and the weakness of the representative boards went to the heads of NUPPO's leaders. They made demands regarding recognition of the union, pensions, overtime, and victimization of union members. They made dubious claims regarding membership, including that ninety percent of most forces had joined the NUPPO ${ }^{98}$. But they miscalculated, assuming that policemen wanted a union rather than being forced into it by the extremities of wartime. Most policemen had experienced the 1918 strike from a distance and could put off the reality of a strike call. In spite of the results, many 
felt uncomfortable that the 'no strike' policy had been abandoned without their input. In London, peer pressure and intimidation had been necessary to convince men reluctant to walk out when the call to strike came. NUPPO contended that their tactics were justified since they needed a majority of policemen striking. They did not understand that with the Desborough Committee meeting in 1919, the NUPPO could no longer say that the union was the only way to get the authorities to listen.

In Spring 1919, police forces organized delegations from all ranks to testify to the Committee on the Police Service of England, Wales and Scotland. City officials and chief constables attended in large numbers. Given the press coverage of NUPPO activities throughout the country as well as reports from their own forces, chief constables and other authorities could not pretend that everything was fine now that the London strike was over and the Met scale in place. Many of the policemen elected by their colleagues to testify were NUPPO members or from representative boards. Many had served in the war. While few of these men supported a strike policy, their membership in the NUPPO indicated their commitment to changing the way policing was organized. Committee questioning of witnesses was detailed and relentless. Witnesses giving vague or inaccurate answers were pressed hard; high-ranking officials giving poor responses found themselves forced to admit their ignorance. Committee members became impatient with police authorities insisting that police pay was basically adequate but then qualifying this when pressed for details ${ }^{99}$. Caldwell had to concede that he had no knowledge of family budgets for constables and was surprised to learn that they were stretched to the limit ${ }^{100}$. While policemen were also challenged when making broad claims regarding pay and representation, their exaggerations out of a desire for better treatment created a better impression than officials ignorant of conditions in their own cities.

The committee soon realized that even the new Met scale was insufficient to support a police family at the respectable level expected of them. Less than a year after calling the Met scale perfectly adequate, chief constables suddenly acknowledged what their men had been telling them about budgets. Caldwell and Peacock advocated a base pay for constables of sixty-four shillings per week, compared to seventy-two shillings per week for dock laborers, calculating that benefits added twenty percent to the value of the wage. Other authorities agreed ${ }^{101}$. Police witnesses before the Desborough Committee recommended a scale beginning at eighty or ninety shillings a week ${ }^{102}$. Men argued that their pay should be higher since «the public generally value a thing according to the price they pay for it» and «it is necessary for the public safety that he should be placed beyond such influences» as corruption and bribes ${ }^{103}$. In July 1919, the committee recommended a new pay scale beginning at seventy shillings a week, more than double pre-war scales, and that free housing be provided through allowances or police housing. The committee agreed that policemen's special relationship with the community required that they maintain a respectable standard of living, free from the temptations of bribes and tips ${ }^{104}$. They concluded that police work had changed so materially over the last twenty years that their new responsibilities should be recognized and rewarded ${ }^{105}$. The Desborough committee decreed that policemen were skilled workers, probably one of the most important achievements of the 1918 strike.

With the Desborough Committee meeting and rumored to be recommending a substantial pay increase, the NUPPO struggled to keep momentum. In May 1919, NUPPO leadership sent out a misleading national ballot, a yes vote comprehending a demand 
for better pay, reinstatement of P.C. Spackman dismissed for union activities, and the right to strike. In reaction to the ballot, chief constables warned that any policemen participating in a strike would be dismissed without pension rights. The Liverpool statement added that «fear of intimidation will not be accepted as an excuse for failing to parade for duty» ${ }^{106}$. With the war over, authorities could take a firm stand. Most policemen preferred to wait and see what the Desborough Committee recommended before taking action. On 1 June, the NUPPO claimed that nearly 45,000 ballots were in favor of the right to strike and that under 5,000 were against $i^{107}$. But on 13 June, the Review reported that the Manchester branch of the NUPPO had voted against a strike and that many were resigning from the union now that pay demands had been satisfied ${ }^{108}$.

Despite the questionable June ballot, the NUPPO called for a strike when the 1919 Police Act under consideration in parliament clearly banned police membership in unions. The act required policemen to resign from organizations and imposed penalties on anyone 'causing disaffection'; as a compromise between a union and no association at all, it included a Police Federation, recognizing that representation was needed. Policemen feared that the federation would be used to punish anyone who opened «his mouth for the ventilation of any just grievance» ${ }^{109}$, but most men would not strike to protest the ban on the NUPPO. The call to strike was undermined even more when the Desborough Committee issued their recommendations for the new pay scale on 1 July. The government announced a $£ 10$ advance on new police wages to be given out on 31 July, the day called for the strike ${ }^{110}$. Even before the official announcement, watch committees let their forces know that they planned to adopt the new scale, taking effect retroactively on 1 April $^{111}$. All this took the wind out of the union's sails. And the Desborough Committee was still meeting to discuss its final recommendations. Since it had already responded favorably to police pay concerns, most policemen hoped that its final report would satisfy their grievances.

On 31 July 1919, despite rumors that ninety-five percent of the Manchester men had struck, a meeting of their union branch voted unanimously to remain loyal to their oath $^{112}$. P.C. Houlden told the meeting that "There was a force somewhere in this country trying to lead the National Union of the Police to become the thin end of the wedge for a social revolution (Cheers). He hoped they in that room would say unanimously, 'This must not be in Manchester' (Cheers)»" ${ }^{113}$. They did send a statement to the government requesting that offending clauses in the Police Bill be deleted or altered and they requested that the new Police Federation be allowed to address individual cases of discipline and promotion. Manchester policemen believed that the recommendations of the Desborough committee met their goals of representation and recognition as a skilled career.

If Manchester men were more or less satisfied, Birmingham men were less optimistic. Their watch committee had a reputation as one of the worst in England and chief constable Rafter was hostile to the idea of a police association of any kind ${ }^{114}$. Rafter made them unwilling to trust authorities to protect their interests, as he insisted that he did. Wartime experience as sergeants or drill instructors made it difficult to accept a return to unfair networks and their subordinate positions. The atmosphere was tense. P.C. Sinclair told the Desborough Committee, «Every member of the Force who knows of any cases of unjust treatment feels that possibly it might be his turn next. Naturally, through that fear, he turns to the Union, knowing that unity is strength» ${ }^{115}$. Many were 
not convinced that the Desborough committee would address their grievances without another show of strength by the union.

The call to strike was answered in Birmingham by at least one hundred and nineteen men, including three sergeants, nine percent of the total strength of thirteen hundred and forty ${ }^{116}$. More men went on strike but later snuck back on duty. Others were not reported by their superior officers immediately, allowing them to change their minds when the strike's failure became obvious. The overwhelming majority of strikers had good service records and possibly felt that their careers had stalled due to lack of connections ${ }^{117}$. The leader, P.S. Edward Taylor, one of the officers who had rescued Lloyd George from rioters in 1901, was quickly dismissed «for inciting men to leave their duty and going out on a Police Strike» ${ }^{118}$. By 3 August, Rafter congratulated men who remained «staunch and true to their honourable undertakings». Rafter blamed the strike on prison warders, rather than on police officers, again refusing to admit that his men might have grounds for discontent ${ }^{119}$. He reminded the watch committee, facing the expense of replacing strikers, that «the men who had been dismissed from the Force were not workmen within the meaning of the [Trades Disputes Act 1906] and that therefore Police Strikers were not entitled to indulge in picketing» ${ }^{120}$. Policemen who had not gone on strike urged that an enquiry be made «for the purpose of punishing the real offenders and the exculpation and rehabilitation of those who are found deserving». But a delegation from 'A' division failed to convince Rafter to consider reinstating strikers ${ }^{121}$. The Birmingham strike failed and the strikers were never rehired. Rafter would not even allow a voluntary collection on behalf of strikers in $1920^{122}$.

Policemen in Liverpool were also not convinced that the Desborough Committee could fix the problems disgracing their force. A union seemed required to pressure local authorities. Wartime had heightened street constables' animosity towards clerk constables, seen as avoiding dangerous assignments, and war had amplified Liverpool's religious tensions. Men returned from the trenches to find themselves out of touch with old networks or left outside of new ones. With the NUPPO, they found they had a network of their own that was taken seriously by authorities. In testimony to the Desborough Committee, P.S. Miles told how he had been passed over for promotion in spite of his 'clean book' and his passing the sergeants exam. He only gained sergeant's rank when the NUPPO put pressure on chief constable Caldwell, who admitted to the committee that Miles had a genuine grievance ${ }^{123}$. The success of the NUPPO in Miles' case and the hope that it created made support for the union much stronger in Liverpool than in any other city.

In Liverpool, at least a thousand men out of twenty-two hundred answered the call to strike ${ }^{124}$. Even the crack 'A' division, the fast track to promotion, had eighty percent of its constables on strike ${ }^{125}$. Rumors spread regarding strikes in other cities, claiming that Manchester and London were nearly all on strike, when actually the opposite was true $^{126}$. P.S. George Miles urged strikers to remain firm since «they had fought for liberty in France but now they were fighting for themselves» ${ }^{127}$. The shortage of policemen led to two days of rioting, destroying streets of shops. After wartime restrictions on food and goods, Liverpool ran wild. Fourteen hundred troops had to be scattered throughout the city, nine policemen were seriously injured by looters, and one looter was killed by a soldier. The battleship, H.M.S. Valiant, and two destroyers were sent to protect the docks ${ }^{128}$. Police pensioners were recalled and new recruits 
were rushed onto the streets ${ }^{129}$. Due to the critical situation, the watch committee agreed to reinstate strikers who returned to duty before 8:00 p.m. on 1 August, hoping to encourage back any men striking through intimidation ${ }^{130}$. But only fifty-four men responded.

Pent-up resentment and tension exploded into reckless activity among policemen as well as civilians. Groups of strikers wandered the city, pressuring colleagues to strike. «Pickets or extremists» intimidated men into not reporting for duty ${ }^{131}$. Pickets threatened P.C. Summersall with "personal violence» if he did not go home. When he reported for duty the next day, he had been dismissed ${ }^{132}$. On the strike being declared, P.C. Swift wrote out his application for his pension and went to regulate traffic. A large crowd of strikers harassed him so he went home. He stayed home for a week, later saying, «I never refused duty until I was terrorised» ${ }^{133}$. It is difficult to know how many men claiming intimidation actually struck voluntarily, caught up in the intensity of the moment. The ambiguous feelings of even voluntary strikers were shown by striker P.C. Morley who arrested two men for breaking and entering shops during the looting on 3 August ${ }^{134}$. Other strikers appalled by the rioting asked to be readmitted to help restore order but without success ${ }^{135}$. Lacking the urgency of wartime, this strike failed. As in Birmingham, loyal policemen were rewarded and strikers punished. The watch committee did not grant strikers arrears in pay until Christmas Eve, 1919136. Caldwell condemned the strikers for violating their oath of office and for destroying the confidence of citizens in the force. He called men striking through intimidation guilty of «folly and cowardice». Readmitting them would be an insult to the loyal men who remained on duty ${ }^{137}$.

Even though the 1919 strikes failed, it took place while the Desborough Committee was still meeting, forcing the committee to recognize that police discontent was not simply a matter of pay. They had to take seriously testimony regarding representation, favoritism and corruption. That another major strike could happen so soon and could again take authorities by surprise made committee members wonder if police leadership was simply incompetent. Both the 1918 and 1919 strikes uncovered a disturbing lack of awareness by police authorities of their own men's resentment of unfair practices in addition to their ignorance of their men's ability to live on their wages. To maintain a viable police force, the committee needed to establish communication between the ranks and commanding officers. Abuse of promotion and discipline had to be ended before it created the disintegration of loyalty seen in Liverpool. Watch Committees had to stop assuming that concerns from policemen were unimportant or exaggerated. The economic status of policemen had to be high enough to compensate for the rigors of the job. Eleven hundred Liverpool and Birmingham fired strikers were casualties of these belated realizations ${ }^{138}$.

The 1920 report of the Desborough Committee reflected efforts to address every facet of police life. Training and education were to be improved and a standard instruction book issued. The weekly rest day and annual leave were regularized to prevent watch committees from meddling to save money. Disciplinary authority was given to chief constables with the right of men to appeal dismissal to a tribunal appointed by the Secretary of State. Promotion was to be based on standard national examinations as well as chief constable's recommendations. To help improve the quality of leadership, no one without police experience could be appointed as chief constable except in exceptional cases. Matters concerning pay, pensions, medical care, and various 
allowances were carefully outlined. To ensure that forces were following these recommendations, the number of inspectors of constabulary was increased ${ }^{139}$. While the report outlined an ideal situation, policemen could now point to the committee's recommendations if local authorities diverged from the plan.

The committee did not support a police union. Instead, they recommended a Police Federation, showing some progress from the 1913 circular barring an association of any kind. But the federation remained as weak and ineffectual as the representative boards. The lack of support was tied to its official creation ${ }^{140}$. Almost immediately, the Birmingham watch committee reminded its branch that «the Police Force is organised to perform Police Duty, and whilst the Police Authority is conveniencing Members of the Force as much as possible, the performance of Police Duty must always be the first consideration»" ${ }^{141}$. Even though the Desborough committee stated that «we regard the maintenance of a sound esprit de corps and relations of mutual confidence between the various ranks as one of the principal tests of the efficient management of a police force ${ }^{142}$, the federation did not provide an effective mechanism for mutual confidence. The potential for explosion remained.

Sadly, efforts to improve the quality of policing and fairness of promotion created an unpleasant split between men recruited after the war and men remaining from beforehand. The 'old police' had survived harsh times together. They resented 'new men' who not only benefited from the 1919 Police Act without having paid for it but who often considered the 'old men' to be inferior policemen. The new promotion examinations were difficult for men hired under pre-war education standards who saw 'new men' with little experience promoted ahead of them. The Desborough Committee urged that promotion not be by examination results alone, «because of the importance of initiative, tact, judgment, and other personal qualifications which cannot be gauged by means of an examination paper,» but no system for measuring these qualities was defined. A recommendation to have 'experience points' added into examinations scores was never implemented ${ }^{143}$. But for new recruits, the pay was good, and the force was transforming into 'the service' and a real career. Stories of pre-war injustice and wartime privation must have appeared to be tales of frustrated old union sympathizers to men who did not live through them.

BIBLIOGRAPHY

\section{References}

Allen, V.L., The national union of police and prison officers, Economic History Review, 1958, 2nd series, 50, 1, pp.133-143.

Bean, R., Police unrest, unionization and the 1919 strike in Liverpool, Journal of Contemporary History, 1980, 15, 4, pp. 633-653. 
Emsley, C. The English Police: a Political and Social History, second edition, New York, Longman, 1996. King, J., The United Kingdom police strikes of 1918-1919, Police Studies, 1988, 11, 3, pp.128-138. Nott-Bower, W., Fifty-Two Years a Policeman, London, Edward Arnold and Co., 1926.

Parliamentary Papers, Report of the Committee on the Police Service of England, Wales, and Scotland. Part I, 1919, Cmd. 253, Vol. XXVII, 709; Part II, 1920, Cmd. 574, Vol. XXII, 539; Evidence, 1920, Cmd. 874, Vol. XXII, 573.

Parliamentary Papers, Report of the Inspectors of Constabulary 1910.

Police review and parade gossip.

Reiner, R. The Blue-Coated Worker: A Sociological Study of Police Unionism, Cambridge, Cambridge University Press, 1978.

Reynolds, G., Judge, A, The Night the Police went on Strike, London, Weidenfeld and Nicolson, 1968.

Sellwood, A.V., Police strike - 1919, London, W. H. Allen, 1978.

Shackleton, R, The 1919 police strike in Birmingham, in Wright, A., Shackleton, R., (Eds.), Worlds of Labour: Essays in Birmingham Labour History, Birmingham, University of Birmingham, 1983.

Steedman, C., Policing the Victorian Community: the Formation of English Provincial Police Forces, 1856-80, London, Routledge \& Kegan Paul, 1984.

\section{Archives}

European Centre for the Study of Policing, Milton Keynes

Chief Constables' Association Annual Reports

Dixon, A., The Home Office and the Police between the Two World Wars, London, the Home Office, 1966.

Greater Manchester Police Museum

Manchester City Police General Orders

Manchester City Police Roster Cards

Manchester Watch Committee Minutes

Liverpool City Local History Library and Archives

Orders of the Liverpool Watch Committee to the Head Constable

Liverpool Watch Committee Minutes

Merseyside Police Authority

Liverpool City Police Chief Constable's Orders

Liverpool City Police Pensioners Register

Liverpool City Police Reports of Constables Injured

Liverpool City Police Strike Book

Short history of members of 'A' division. during first ten days of police strike August 1st to 10th 1919, anon., n.d.

West Midlands Police Authority

Birmingham City Police Orders 
Birmingham City Police Roster Books

Birmingham City Police Superintendent's Reports and Confidential Letters

Birmingham Minutes of the Judicial Sub-Committee

Birmingham Watch Committee Minutes

\section{NOTES}

2. Desborough Committee (DC)(Evidence 1920, pp. 184, 173). P.C. William Sinclair, Birmingham City Police, stated, «We believe that policemen have for years suffered in silence; they have had no medium through which they could voice their grievances excepting through a few friends in Parliament» (DC [Evidence 1920, p. 297]).

3. Steedman (1984, p. 93), Manchester City Police Roster Cards, 1900-1919. This trend continued from 1920 to 1939, with about twenty percent leaving with less than five years and fifty-five percent making it to retirement age.

4. Allen (1958, p. 133); Emsley (1996, pp. 97-98)

5. Manchester Watch Committee Minutes (MWCM) (1 March 1901, vol. 13, no. 103) copy of complete oath.

6. Liverpool called their chief the 'head constable' until 1919.

7. Letters to the Police Review complained endlessly about 'anti-Romish domination', Freemasonry, and nepotism within the Liverpool City Police. Even making allowances for exaggeration, letters from this city far outnumber those from anyplace else.

8. Policemen began communicating across force lines at the same time that the Chief Constables Association, also founded in 1893, was providing similar opportunities for those in higher positions of authority. The CCA, which included the heads of borough forces, compared local conditions in a national forum similar to the Review (Emsley, 1996, pp. 100-101).

9. Police Review and Parade Gossip (PR) (12 January 1900, pp. 15-16). Forty-six forces began at 24/-; twenty-two at 23/-; twenty-one at 25/-; fourteen began at 22/-; eleven at 21/-. A handful of forces made 26/- or 27/- a week and a couple made 20/- or 19/-. Very small forces paid both high and low wages so size alone was not the deciding factor. Larger than most forces, Birmingham had a strength of 700 men; Liverpool had 1460; Manchester 1031.

10. MWCM (22 March 1900, vol. 10, no. 71; 13 June 1900, vol. 10, no. 138); PR (30 March 1900, p. 154; 22 June 1900, p. 291).

11. PR (30 March 1900, p. 153). See also PR (12 April 1900, pp. 175-176). Some committee members did object that it was inappropriate to take this action in light of their not paying policemen a shilling or two more a week, but they were over-ruled.

12. PR (22 June 1900, p. 291).

13. Manchester City Police General Orders (MGO) (6 February 1901).

14. Superintendents and inspectors tended to petition separately, reflecting problems with crossrank communication.

15. Liverpool Watch Committee Minutes (LWCM) (23 July 1900, pp. 172-176); PR (21 September 1900, p. 448); Liverpool Orders of the Watch Committee to the Head Constable (LWCHC) (26 November 1900).

16. PR (28 June 1901, p. 303; 25 October 1901, p. 508; 1 November 1901, pp. 519-520). Birmingham's watch committee did approve pay increases for superintendents and inspectors in 1901, which did little for morale in the ranks. (PR [18 October 1901, p. 496]).

17. Birmingham City Police Orders (BPO) (23 November 1901, p. 574).

18. BPO (23 November 1901, p. 574) 
19. PR (28 June 1901, p. 303; 25 July 1902, p. 351; 13 February 1903, pp. 75-76).

20. Birmingham's day beats ran in split shifts, the first from six to ten a.m. and two to six p.m., and the second from ten a.m. to two p.m. and six to ten p.m. The men requested that eight-hour shifts be instated since split shifts forced constables to spend double tram fares every day travelling to and from work or else spending the four-hour intermediate period wasting time in the city. The policeman's health was the unvarying defense for split shifts(Birmingham Watch Committee Minutes [BWCM] [15 July 1903, pp. 448-452]). The issue was revived in 1928. The watch committee replied, «eight hours continous [sic] tour of duty on the streets, with only a short interval for meals, would involve heavy strain upon a man's physique and a continous [sic] lowering of the vitality, with a resultant increase in liability to sickness». In 1932, another request received a similar answer, adding that continuous shifts would require the expense of hiring relief for meal times. Finally, in 1937, the committee agreed to try eight-hours shifts on a trial basis for one year. In April 1938 chief constable Moriarity informed the committee that no difficulties had been experienced and the health of the men was sound (BPO [30 January 1928, p. 13779]; BWCM [6 April 1931, report no. 1, p. 3; 7 April 1938, report no. 5, p. 4]).

21. PR (7 August 1903, p. 381).

22. LWCM (14 May 1907, pp. 350-354). This budget is similar to many submitted to the Police Review by police wives.

23. PR (12 January 1906, p. 20).

24. PR (11 March 1904, p. 124). Pensioners could not be fired though they still risked losing their pensions, however, if watch committees decided they had violated their pension terms.

25. PR (1 June 1906, p. 261).

26. Sellwood (1978, p. 94).

27. BPO (1 August 1907, p. 116).

28. MWCM (January 1909, vol. 42, no. 77).

29. PR (17 January 1908, p. 34).

30. PR (10 September 1909, p. 442).

31. Birmingham Evening Dispatch as quoted in PR (11 February 1910, p. 70).

32. PR (10 September 1909, p. 442).

33. PR (22 October 1909, p. 507).

34. PR (22 October 1909, p. 507).

35. Emsley (1996, p. 133).

36. LWCM (12 February 1912).

37. The bad reputation of the 'clerk track' went beyond city boundaries. Inspector Thomas Dale of Newcastle-upon-Tyne City Police stated, when asked about the practice of improper promotion of office clerks, «I think Liverpool is the most prominent in the minds of the police generally.» (DC, Evidence 1920, p. 129). Unlike the copper plate found in most police record books, Liverpool's records were often illegible, the clerks having their positions due to connections rather than skills.

38. MGO (7 April 1911); MWCM (20 February 1912, vol. 53, no. 183).

39. PR (8 March 1912, p. 111).

40. PR (8 March 1912, p. 111).

41. PR (31 October 1913, pp. 523-524). The possibility of internationally affiliated police unions made governments even more leery of allowing local ones.

42. Emsley (1996, p. 99).

43. PR (26 September 1913, p. 459).

44. In January 1914, a deputation of Manchester inspectors, sergeants and constables unhappy with changes in retirement qualifications decided to be represented by counsel in their dealings with the watch committee, hoping to give their petition more weight. Trouble began when the committee had granted new scales of pay effective January 8, 1914. Constables began at 28 
shillings per week, reaching 35 shillings after six years (MGO [8 January 1914]). It was the first pay increase since 1901. However, the new scale upset advantages under the old scale for about three hundred men regarding when they could retire (PR [16 January 1914, p. 31]). These men, along with their counsel, petitioned the watch committee to correct the anomaly but the committee decided against any alterations to the new scale (MGO [31 January 1914, 3 February 1914, 14 March 1914]). The rejection rankled. A Review article described the continuing sense of grievance among the older men "at the mercy» of the watch committee (PR [5 February 1915, p. 67]). Their inability to have an impact on the committee, even when legally represented, helped push Manchester policemen towards becoming among the most active supporters of a union.

45. PR (24 October 1913, p. 508).

46. BPO (30 October 1913, p. 587).

47. PR (19 December 1913, p. 609); BPO (30 October 1913, p. 587).

48. PR (31 October 1913, pp. 523-524).

49. Emsley (1996, p. 99).

50. MWCM (25 April 1918, no. 106, vol. 76); November 1913 letter quoted in discussion of union appearing in 1918.

51. BWCM (8 October 1917, p. 159) copy of August 1914 Scale of Pay.

52. Immediately, Birmingham policemen in the military had a grievance because their wives received an allowance of twelve shillings a week while Manchester and Liverpool wives received fifteen. (BWCM [7 August 1914, pp. 114-115]; MGO [20 August 1914]; LWCM [12 June 1917, p. 476]). In Birmingham, children under age fifteen received 2/-, parents dependent on an unmarried son receiving 8/-. The Manchester and Liverpool rates were about the same.

53. Policemen had to get permission to enlist since forces could not afford to have too many men leave at once and since policemen had important duties on the home front. In December 1916, Birmingham had 300 men in the army and navy; 6 months later Manchester had 700 men in the services (BWCM [19 December 1916, p. 2]; MWCM [7 June 1917, vol. 74, no. 20]).

54. MGO (8 January 1914).

55. PR (22 October 1915, p. 507). See PR (18 February 1916, p. 75) for letters from Manchester and Liverpool constables.

56. MWCM (21 March 1916, vol. 70, no. 32).

57. PR (31 March 1916, p. 151).

58. MWCM (3 April 1916, vol. 70, no. 54); MGO (13 April 1916).

59. MWCM (4 January 1917, vol. 73, no. 19).

60. DC (Evidence 1920, p. 122); also PR (22 October 1915, p. 507). According to Ministry of Labour figures, building laborers wages had increased $115 \%$, engineering laborers $152 \%$, railway laborers $83 \%$ to $165 \%$, and carters $86 \%$ to $120 \%$.

61. PR (18 February 1916, p. 75; 31 March 1916, p. 151; 24 November 1916, p. 466).

62. PR (1 June 1917, p. 172); BWCM (16 June 1917, p. 103).

63. LWCM (12 June 1917, p. 476); BWCM (3 October 1917, p. 309). Liverpool children received 3/6d; Birmingham children received 3/-.

64. Birmingham constables had a bonus of $2 / 6 \mathrm{~d}$. a week; raised to $4 / 6 \mathrm{~d}$.; then to $9 / 6 \mathrm{~d}$ (BPO [1 September 1915, p. 36]; BWCM [19 December 1916, p. 5; 16 June 1917, p. 103]) Liverpool: 3/- a week to men under $£ 2$ a week pay, 2/- to men over $£ 2$; changed to 6/- for married men, 3/- for single (PR [18 February 1916, p. 75]; LWCM [12 December 1916, p. 98]) Manchester: for extra day duty per week, 6/- a week for constables and 7/- for sergeants; bonuses began January 1917 at 7/a week; then to 9/- and 12/- (MWCM [3 April 1916, vol. 70, no. 54]; MGO [13 April 1916]; MWCM [4 January 1917, vol. 73, no. 19; 16 August 1917, vol. 74, no. 133]; MGO [16 August 1917]; MWCM [15 November 1917, vol. 75, no. 56]; MGO [21 November 1917]).

65. PR (3 August 1917, p. 243).

66. MGO (5 August 1914, 27 November 1914, 22 June 1915). 
67. BPO (8 January 1919, p. 403).

68. MGO (13 April 1916); LWCM (29 November 1917, p. 28); BPO (8 January 1919, p. 403).

69. PR (11 December 1914, p. 596).

70. BWCM (8 October 1917, p. 159).

71. PR (18 January 1918, p. 19).

72. LWCM (29 November 1917, p. 28); MGO (21 March 1918); MWCM (10 April 1918, vol. 76, no. 99; 7 August 1918, vol. 77, no. 65; 22 August 1918, vol. 77, no. 72). Liverpool bonus to 10/8d., 2/- child allowance, then to 13/4d (LWCM [29 January 1918, pp. 152-153; 28 May 1918, p. 342]) Birmingham to $13 / 6 \mathrm{~d}$ and then to 20/- (BWCM [1 May 1918, p. 301; 22 July 1918, p. 345]; BPO [30 July 1918, p. 87]).

73. MWCM (25 April 1918, vol. 76, no. 106).

74. MWCM (22 August 1918, vol. 77, no. 72); MGO (29 August 1918).

75. King (1988, p. 133).

76. Short accounts of the 1918 and 1919 strikes from the official point of view are given in Dixon (1966, pp. 5-20) and Nott-Bower (1926, pp. 283-302). The police point of view is given in Reynolds and Judge (1968). On the NUPPO, Allen (1958); on Birmingham, Shackleton (1983); on Liverpool, Bean (1980, pp. 633-653); also Sellwood (1978) and King (1988).

77. PR (13 September 1918, p. 292); also PR (6 September 1918, pp. 283-286).

78. King (1988, p. 134).

79. Dixon (1966, p. 6).

80. PR (13 September 1918, p. 293).

81. PR (6 September 1918, p. 286); Shackleton (1983, p. 65); Birmingham City Police Superintendent's Reports and Confidential Letters (BRCL) (2 November 1918, pp. 500-501).

82. MGO (5 September 1918).

83. PR (13 September 1918, p. 293; 6 September 1918, p. 286); MGO (2 October 1918); PR (11 October 1918, p. 324) reprinted letter and reply in full under title, "The Manchester Ultimatum»; PR (18 October 1918, p. 334).

84. $\mathrm{MGO}(2,8$ October 1918).

85. MGO (10 October 1918); MWCM (17 October 1918, vol. 77, no. 117).

86. Liverpool City Police Chief Constable's Orders (LCCO) (3-7 September 1918, pp. 21-23).

87. LCCO (7 October 1918, p. 39). The vote was 568 for keeping children's allowance, 556 for adopting a flat rate, with 98 ballets blank (LCCO [15 October 1918, p. 42]). Only 1222 men out of approximately 2200 voted.

88. PR (18 October 1918, p. 334). Smithwick later became the constables' representative to the Desborough committee and PS George Miles, another active member of NUPPO, the sergeants' representative.

89. BRCL (2 November 1918, p. 502).

90. «Birmingham City Police Revised Scale of Pay (To date from 2nd September, 1918)»; BWCM (9 October 1918, p. 401).

91. BPO (7 October 1918, pp. 257-259); PR (18 October 1918, p. 334). The watch committee set up the arrangements for the police committee (BWCM [9 October 1918, pp. 261-263]).

92. BRCL (2 November 1918, pp. 499-502).

93. DC (Evidence 1920, PC William Sinclair, BCP, p. 299); PS William Clowes, BCP, representative committee secretary, also testified.

94. BPO (5 April 1919, p. 658).

95. MGO (5 September, 26 November 1918, 11 January 1919); DC (Evidence 1920, Inspector S. Latham, MCP, p. 169; P.S. Matthew Seaman, MCP, p. 174).

96. MGO (13 February 1919); PR (21 February 1919, p. 60).

97. LCCO (18 November 1918). Reynolds, Judge and Sellwood state that police authorities in Liverpool forbade formation of the boards but this vote result would contradict that conclusion. 
98. PR (2 May 1919, p. 150).

99. In a typical exchange, Sir Francis Blake and Captain James O'Grady made short work of Mr. C. Courtenay Hodgson, Clerk of the Peace, Cumberland, who stated that police pay was satisfactory but then had to admit that men could not live on the current scale. (DC [Evidence 1920, p. 433]).

100. DC (Evidence 1920, p. 277).

101. DC (Evidence 1920, Alderman J. Swaish, Bristol, p. 262; Councillor C.F. Haigh, Leeds, p. 262; Mr. C. Courtnay Hodgson, clerk of the peace, Cumberland, p. 433; Mr. G.H. Gardner, New Scotland Yard, p. 64; pp. 110, 276-277).

102. DC (Evidence 1920, Inspector Samual Latham, MCP, p. 166; P.S George Miles, LCP, p. 186; Sergeant William Clowes, BCP, p. 295). Weekly earnings of other employments included corporation street sweepers, 55 shillings; tram drivers, 65 shillings; cotton porters at Liverpool docks, 68 and a half shillings; and London unskilled laborers, 68 shillings (DC [Part I,1919, p. 9]).

103. DC (Evidence 1920, pp. 184, 188, 303).

104. DC (Part I,1919, p. 8).

105. DC (Part I,1919, pp. 5,7,9,13).

106. BPO (30 May 1919, pp. 798-799); MGO (31 May 1919); LCCO (31 May 1919).

107. PR (8 August 1919, p. 318).

108. PR (13 June 1919, p. 226).

109. PR (15 August 1919, p. 328). Because of the prohibition against policemen belonging to any association discussing issues of pay, pension or conditions of service, the Chief Constables Association changed their bylaws to conform with the Police Act, 1919. The chief constables vehemently denied that their association was in any way a union (Chief Constables Association Annual Report, [4 June 1920, p. 9]).

110. BWCM (23 June 1919, p. 63; 23 July 1919, p. 88); BPO (31 July 1919, p. 968 ; 12 August 1919, pp. 1003-1004); MGO (30 July 1919); Allen (1958, pp. 136, 138-139).

111. BWCM (23 June 1919, p. 63); officially adopted scale and $£ 10$ advance on 23 July 1919 (BWCM [23 July 1919, p. 88]); MGO (30 July 1919).

112. MGO (5 August 1919).

113. PR (15 August 1919, p. 328).

114. Policemen complained about victimization in the latest round of promotions which passed over all union members, hardly surprising given Rafter's hostility towards the organization (PR [2 May 1919, p. 150]).

115. DC (Evidence 1920, pp. 297-298).

116. 'A' division lost 42 men, 'C' lost 38 and ' $E$ ' lost 39. For some reason, 'B' division only lost one man. 118 were regular police, one a police reservist. Two had twenty years experience or more, 22 had fifteen to nineteen years, 30 from ten to fourteen years, 49 from five to nine years, 16 had less than five years. A complete list of the men dismissed is in the BWCM (5 May 1920, pp. 13-22) and in BPO (2-3 August 1919, pp. 972-975). 112 of the men were married (PR [11 March 1927, p. 182]).

117. Shackleton (1983, pp. 71-73, 78); BPO (2, 3, 4 August 1919, pp. 972-975, 978-979; 3 August 1919, pp. 976-977; 15 August 1919, p. 1016). To reward men who stayed on duty, all disciplinary reductions in class were canceled in calculating the new scale of pay and, initially, dismissed strikers received no arrears in pay. This was changed in January 1920 since it was not legal (BPO [5 August 1919, p. 980]).

118. Birmingham City Police Roster Book (2 August 1919, PSC Edward Taylor, joined September 1896); Shackleton (1983, p. 63).

119. BPO (3 August 1919, pp. 976-977). Shackleton argues that «the intensity and genuiness of the commitment of the Birmingham trade-union movement to the cause of the strike was clearly demonstrated» in statements made after the strike was lost.(Shackleton [1983, p. 80]). Yet, no help was forthcoming until it was clearly too late to be of the slightest use. The National Union of 
Railwaymen met and decided against a sympathy strike though the Licensed Vehicle Workers' Union requested the TUC and the National Transport Federation to take action to support the police strikers (PR [15 August 1919, p. 328]).

120. BWCM (4 August 1919, p. 95).

121. BWCM (15 August 1919, pp. 108-109; 1 September 1919, p. 120).

122. Birmingham Minutes of the Judicial Sub-Committee (5 July 1920, p. 163).

123. DC (Evidence 1920, pp. 1943-1949).

124. Bean $(1980$, pp. 641, 645). An initial count of strikers was a low three hundred, a result of men being off duty when the strike was called, making it unclear who was on strike, and of officers trying to protect men that they hoped would change their minds about striking (Liverpool City Police Strike Book [LSB][1 August 1919]).

125. 48 sergeants and 907 constables were dismissed out of a total strength of 2,200 . The average length of service for sergeants was 18 years. 80 constables had 20 years or more, 78 had 15 to 19 years, 171 had 10 to 14 years, 331 five to nine, 91 one to four and 159 under a year's service. An additional 2 sergeants and 52 constables struck but reported for duty by 8:00 p.m. on August 1st. In a log kept of strikers in the ' $\mathrm{A}$ ' division, the division rumored to be the fast track to promotion, 11 out of 50 sergeants struck, 3 later asking for readmission. 186 out of 234 constables struck, $80 \%, 47$ asking for readmission. None of the strikers were readmitted. The official count was 12 sergeants and 184 constables (Short history of members of A div. during first ten days of police strike August 1st to 10th 1919, anon., n.d. ).

126. PR (8 August 1919, p. 323).

127. LSB (1 August 1919, report of John Leathom Flood, a Lever Brothers clerk present at the meeting; report of Birkenhead Inspr. Birch).

128. LSB (2 August 1919, report of the chief constable on disposition of troops and magistrates); Liverpool City Police Reports of Constables Injured (3-4 August 1919); Reynolds and Judge (1968, pp. 168-169); Dixon (1966, p. 18).

129. LCCO (7, 10 August 1919 and following); PR (18 March 1921, p. 150); LWCM (19 August 1919, pp. 453-455); LCCO (20 August 1919); LWCM (30 September 1919, p. 670). Pensioners were not released from duty until May 1920 (LCCO [5 March 1920]).

130. LCCO (1 August 1919); LSB (1 August 1919).

131. LSB (3 August 1919, report from Inspector N. Ford to Chief Superintendent 'A' Division).

132. LWCM (11 January 1921, pp. 442-445). Due to Summersall's eye injury while on duty in 1918 which was progressing towards blindness, the chief constable agreed to «see what can be done in the matter» in spite of Summersall's striker status.

133. LWCM (17 February 1920, pp. 486-487). He was given his pension since he qualified for it when he applied for it.

134. LSB (2 August 1919, report of the Chief Supt. of A Division on 3 strikers asking to be taken back; 4 August 1919, report of Inspr. Ford; 16, 22 August 1919, two reports of P.S. Mybroie).

135. LSB (3 August 1919, report from Inspector N. Ford to Chief Superintendent 'A' Division).

136. LSB (22 December 1919, chief constable's order). For those who worked continuously, grants of four weeks pay were given; those recalled from leave or illness and worked extra hours, three weeks; those who remained loyal but did not work long hours, two weeks; those who returned to duty after striking and remained loyal, one week.

137. LSB (Police Orders, letter from Head Constable Caldwell to the Liverpool City Police). Nine strikers prevented from taking their pensions due to the war were allowed their pensions calculated on the pre-Desborough pay scale when the war officially ended in August 1921. Eight had 25 years service, one 26 years (LWCM [17 February, 11 May 1920, pp. 484-487, 689]; Liverpool City Police Pensioners Register [31 August 1921]). 
138. In 1919 in London, just over a thousand policemen were fired for striking. The strike there was similar to Birmingham, with enough men striking to show dissatisfaction but not enough to cripple the force as in Liverpool (Reynolds, Judge, 1968, p. 143).

139. DC (Part II, 1920, pp. 23-25).

140. The federation was not restructured into a real negotiating body of the rank and file until the late 1940 s in response to heavy attrition rates, before which time no proper negotiating or arbitration machinery existed. See Reiner (1978, pp. 30, 54, 88ff).

141. BPO (20 December 1919, p. 1554).

142. DC (Part II, 1920, p. 9).

143. DC (Part II, 1920, p. 10).

\section{ABSTRACTS}

This articles explores how English borough policemen during the early 1900s grappled with how to organize effectively to improve their conditions of service without violating their oaths of office. Policemen faced an increasing load of duties and responsibilities yet suffered from eroding pay scales and lack of recognition. Local watch committee and police forces did not provide policemen with a mechanism for voicing their grievances beyond submitting petitions which were frequently ignored. Frustrated with their lack of progress, policemen searched for ways to make their voices heard. Initially, the obvious choice of a police union was resisted since most men found the possibility of a police strike incompatible with their duties to uphold law and order. However, the pressures of the First World War combined with continued silence from watch committees regarding their grievances finally precipitated the organization of the National Union of Police and Prison Officers (NUPPO) and the calling of police strikes in 1918 and 1919. The parliamentary committee investigating this embarrassing situation traced the roots of the problem to the refusal of police authorities to listen to their own men. National legislation resolved many grievances regarding pay, status and promotions. But the need for policemen to have a voice was less easily resolved. The new Police Federation gave policemen a forum but was viewed with suspicion by the men as an official creation and it could still be ignored by police authorities. A dangerous lack of communication and potential for explosion remained.

Cet article examine comment les policiers municipaux anglais se sont débattus, au début du XX siècle, avec la question de savoir comment s'organiser pour obtenir une amélioration de leurs conditions de travail sans violer les devoirs de leur charge. Alors que la charge de travail et les responsabilités des policiers s'accroissaient, leur rémunération s'érodait et ils souffraient d'une insuffisante reconnaissance professionnelle. Les comités de police locaux et les corps de police eux-mêmes ne fournissaient aux policiers aucun moyen institutionnel de faire connaître leurs revendications, mis à part le recours à des pétitions, au reste fréquemment ignorées. La frustration née de cette situation poussa les policiers à se faire entendre autrement. Dans un premier temps, ils refusèrent de s'engager dans la voie syndicale, la plupart des policiers jugeant l'éventualité d'une grève incompatible avec leur mission de maintien de l'ordre. Les pressions provoquées par la Première Guerre mondiale et le silence persistant des comités de police vis-àvis de leurs demandes amena cependant la création de la National Union of Police and Prison Officers (NUPPO) et à l'appel à la grève en 1918 et 1919. La commission parlementaire chargée d'étudier les causes de cette embarrassante situation les attribua au refus des autorités de police 
d'écouter leurs propres hommes. Une législation nationale régla une grande partie des problèmes touchant aux rémunérations, au statut et aux carrières. Mais la difficulté du problème du droit d'expression des policiers fut plus ardue. La nouvelle Police Federation pouvait constituer un forum, mais elle était perçue avec méfiance par les policiers car c'était une institution officielle, que les autorités locales n'étaient du reste pas tenues d'entendre. Il en résulta une absence menaçante de communication et un risque d'explosion latent.

\section{AUTHOR}

\section{JOANNE KLEIN}

Assistant Professor of History, History Department, Boise State University, 1910 University Drive, Boise, ID 83725-1925, jklein@boisestate.edu

Joanne Klein is Assistant Professor of Modern European Comparative History at Boise State University (Idaho, USA). Her current research interests focus on the everyday life of English borough police constables in the twentieth century with a broader interest in modern British policing in general. 